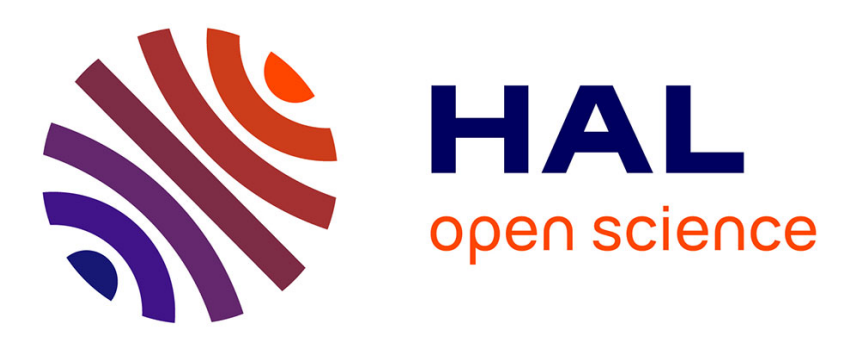

\title{
Cost effectiveness of health expenditures: A macro level study for developing and developed countries
}

\author{
Syeda Anam Fatima Rizvi
}

\section{To cite this version:}

Syeda Anam Fatima Rizvi. Cost effectiveness of health expenditures: A macro level study for developing and developed countries. International Journal of Humanities and Applied Social Science, 2020, pp.26 - 42. 10.33642/ijhass.v5n9p3 . hal-03341702

\section{HAL Id: hal-03341702 \\ https://hal.science/hal-03341702}

Submitted on 12 Sep 2021

HAL is a multi-disciplinary open access archive for the deposit and dissemination of scientific research documents, whether they are published or not. The documents may come from teaching and research institutions in France or abroad, or from public or private research centers.
L'archive ouverte pluridisciplinaire HAL, est destinée au dépôt et à la diffusion de documents scientifiques de niveau recherche, publiés ou non, émanant des établissements d'enseignement et de recherche français ou étrangers, des laboratoires publics ou privés. 
See discussions, stats, and author profiles for this publication at: https://www.researchgate.net/publication/344430376

Cost effectiveness of health expenditures: A macro level study for developing and developed countries

Article in International Journal of Humanities and Applied Social Science · September 2020 DOI: $10.33642 /$ ijhass.v5n9p3

CITATIONS

2

1 author:

Syeda Anam Fatima Rizvi

Université Clermont Auvergne

4 PUBLICATIONS 6 CITATIONS

SEE PROFILE 


\section{Syeda Anam Fatima Rizvi}

PhD Scholar

Development Economics

Université Clermont Auvergne

Clermont Ferrand, France

Email: Syeda_Anam_Fatima.Rizvi@etu.uca.fr

France

\section{ABSTRACT}

Resource availability matters the most in health care system-based outcomes. But health spending is highly unequal across the world and presents varying outcomes. This study aims to investigate the missing part that why some countries failed to have reasonable outcomes despite spending more than those countries that spend less. This study intends to include all those factors that are responsible for improving the costeffectiveness of health expenditures. The study took two data sets, one from the developing countries and second of developed countries as per World Bank classification. As anticipated, there are significant differences in health per capita expenditures. Determinants were also found to behave differently both in the short run and long run as well as across the two data sets.

\section{Keywords: Cost effectiveness, Health Expenditures, Health JEL Classifications: H510, I100}

\section{Introduction}

Out of eight Millennium Developed goals (MDGs) three were related to health and were supposed to be achieved by 2015 . The ambitious nature of these goals was linked with concern about the massive health challenges being faced by the world's poorest countries, which has led to a growing momentum within the field of global health. However current trend proves that despite international support and financial assistance, many low-income countries failed to achieve the target these countries are very far away from the goals. There is a growing consensus that health care institutions in low-income countries are too feeble and fragmented to deliver the desired quantity and quality to those in need. Experience suggests that if health care institutions are short of capabilities like health care financing, drug supply, health workforce, an information system, they may not be able to perform and deliver.

Besides market-based solutions for developed economies, effective interference exists for several key health issues in developing countries; and due to these interventions there is a reduction in prices, and availability of resources has increased. However, despite all these the outcome in terms of achieving the health goals is slow. Thus now there is increasing concern that besides these the health care institutions would be required to be focused as these can help in achieving the desired health goals. Since the subject is in its initial stage there is no consensus on a singular solution. As a first step objective is to understand the dynamics of knowledge about the cost-effectiveness of health expenditures and to investigate that why some countries with low expenditures have reasonable health outcomes as compared to those countries who spend more, yet outcomes are not that encouraging.

There is evidence dispersion in Health expenditures across the globe for example Poullier et al. (2002) examined the health care expenditures for 191 countries for the year 1998 and confirmed that health spending is very unequally spread across countries. Higher health expenditure is linked to better health outcomes, but this relationship presents enormous disparity. Hence, public policy can play a major role in health outcome achievement especially where public resources are involved, even in low health spending countries. Similarly, Evans et al. (2000) measured the overall health performance of 191-member countries of WHO for the period 1993 to 1997. The study found that efficiency for health spending increases with health expenditure per capita and then declines slightly, thus presenting an inverted $U$ type phenomenon.

\subsection{Global health expenditures and outcomes}

From Figure 1 it can be seen that National Health Accounts (NHA) estimates for 2014 show that health spending is extremely unequal around the world. Region of America has only 13\% population of the world but spends the most 
International Journal of Humanities and Applied Social Science (IJHASS)

E-ISSN: 2471-7576

September 2020, Vol: 5, Issue: 9

E-mail: editor@ijhassnet.com

http://ijhassnet.com/

DOI: 10.33642/ijhass.v5n9p3

CCenter for Promoting Education and Research (CPER) USA,www.cpernet.org

on health per person. Similarly, European countries invest a large percentage of their GDP in the health sector. On the contrary, South-East Asian countries have the highest population i.e. 26\% but spend only 2\% of their GDP on average for the Health Sector. Likewise, African countries spend only 1\% of GDP with a population share of $13 \%$ of the world. Table 1 shows that OECD countries spend around 12\% (as a percentage of GDP) coupled with the highest life expectancy than others (more than 80 years). They have the highest private and public expenditure in the health sector. Whereas European and American countries spend 9.5\% and 7.3\% respectively and have a life expectancy of around 70 years. Whereas Sub-Saharan Africa (SSA) is at the lowest place in terms of life expectancy of 58 years and spending of 5.4\% of GDP. But Middle Eastern and North African countries spend almost the same as SSA countries but have a life expectancy of 72 years. While South Asian countries spend less than SSA countries with only $1.3 \%$ public and 3\% private break up but still have better life expectancy i.e. 68 years.

So, there is a dispersion in health sector spending and corresponding outcomes in terms of health outcomes across the globe. Although health spending affects health conditions the most, the efficiency also matters and because of that health outcomes vary significantly among the countries even if the level of spending is the same.

The Scatter plot below (Figure 2) shows the relationship between health status and health spending. The rough differences in health outcomes between countries with similar levels of spending can be seen. Here many countries fall drastically below the levels of health outcomes earned by their peers. In Figure 2 we.

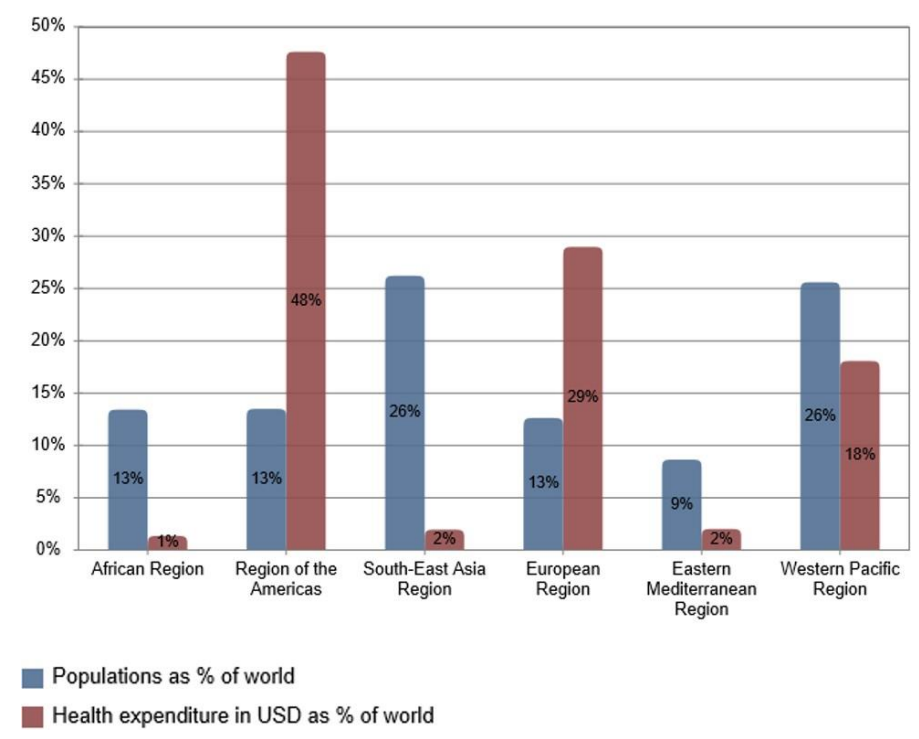

Figure 1: Percentage distribution of population and total health expenditures by WHO regions, 2014 (Source: NHA 2014 Statistics).

Table 1: World health expenditures (Data source: WDI 2014 statistics)

\begin{tabular}{|llllll|}
\hline \multicolumn{1}{|c}{ Region } & $\begin{array}{c}\text { Health } \\
\text { expenditure } \\
\text { per capita } \\
\text { (current US } \\
\text { \$) }\end{array}$ & $\begin{array}{c}\text { Health expenditure } \\
\text { (\% GDP) }\end{array}$ & $\begin{array}{c}\text { Health } \\
\text { expenditure } \\
\text { by } \\
\text { Public } \\
\text { (\% GDP) }\end{array}$ & $\begin{array}{c}\text { Health expenditur } \\
\text { by e } \\
\text { (\% Private } \\
\text { of GDP) }\end{array}$ & $\begin{array}{c}\text { Life } \\
\text { Expectancy }\end{array}$ \\
\hline $\begin{array}{l}\text { East Asia \& } \\
\text { Pacific }\end{array}$ & 639.354 & 6.887 & 4.563 & 2.323 & 74.925 \\
$\begin{array}{l}\text { Europe \& } \\
\text { Central Asia }\end{array}$ & 2419.37 & 9.525 & 7.182 & 2.343 & 77.095 \\
$\begin{array}{l}\text { Latin America } \\
\text { \& Caribbean }\end{array}$ & 714.055 & 7.309 & 3.833 & 3.476 & 74.942 \\
$\begin{array}{l}\text { Middle East \& } \\
\text { North Africa }\end{array}$ & 433.289 & & & & 72.873 \\
$\begin{array}{l}\text { OECD } \\
\text { members }\end{array}$ & 4735.38 & 5.3214 & 3.209 & 2.112 & 80.175 \\
$\begin{array}{l}\text { South Asia } \\
\text { Sub-Saharan } \\
\text { Atrica }\end{array}$ & 66.715 & 12.341 & 7.697 & 4.644 & 68.121 \\
\hline
\end{tabular}


can see three types of trends, first, among the lowest spending countries marginal, higher spending seems to be associated with improvements in health status which supports the inverted $U$ shaped for health spending effectiveness. Secondly, at a very low spending level, some countries have better health status as to others. Thirdly from the perspective of high health spending countries; this extra expense does not cause much of Health Outcome improvement. Which makes it a serious concern for these developed countries to deal with and take measures to restrain it, as outcomes are not that significantly improving. Henceforth justifying that there is a need to see why these differences in health outcomes exist. There could be possible determinants, such as the demographic ratios (old/young), education, per capita incomes, insurance coverage, and technology, etc.

\subsection{Objective of the study}

It is a well-known fact that resource availability matters the most in health care system-based outcomes. But health spending is highly unequal across the world and presents varying outcomes. This study aims to investigate the missing part that why some countries failed to have reasonable outcomes despite spending more.

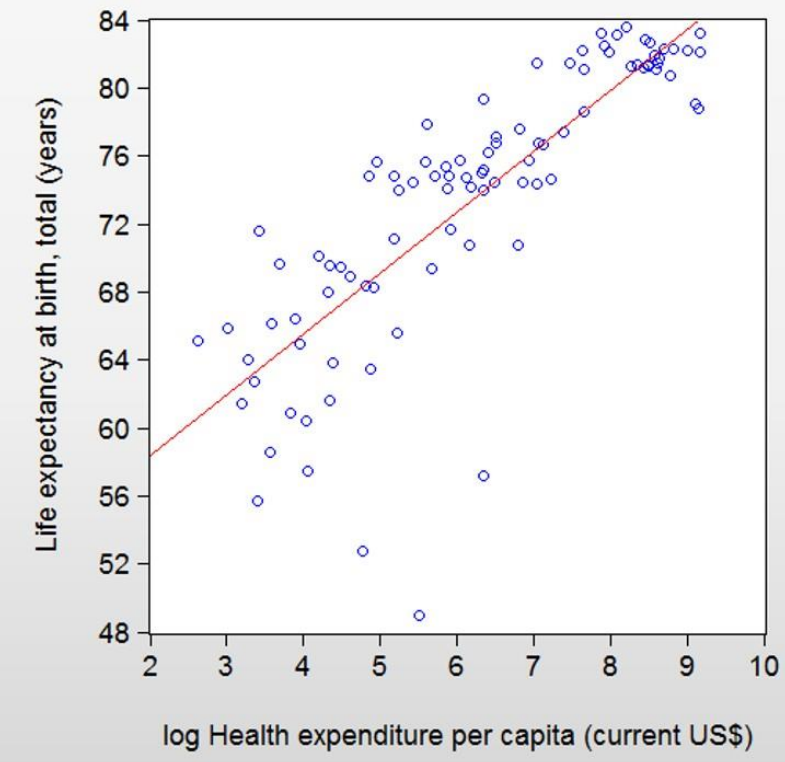

Figure 2: Scatter plot of life expectancy and health expenditures of some countries in 2014.

Then those countries that spend less. The main theme of the study will be the cost-effectiveness of health expenditures at the macro level. Although many factors affect the working of health care institutions and the delivery of health care services. But this study intends to include all those factors that are responsible for improving the costeffectiveness of health expenditures. These could be variables such as:

1. Income

2. Role of technology in health care expenditures

3. Role of institutions for cost-effectiveness.

4. Role of insurance in health outcomes.

5. The complementary role of preventive health care (education).

\subsection{Importance of the study}

This study intends to explore the determinants of health care expenditures efficiency by collecting recent insights from the existing literature and, also by carrying out an empirical analysis to see possible determinants for these differences. This study will help in the future evolution of health care expenditures and policies in developing and developed countries.

\subsection{Organization of the paper}

The introduction of the paper. Section 2 focuses on the determinants of health care expenditures and provides an overview of the literature of these determinants. Section 3 introduces the variables and data. The econometric methods are presented in Section 4. Section 5 discusses the econometric results. Section 6 concludes the study and suggests some policy implications along with the limitations of the study. 


\section{Key Findings from Previous Studies: Factors responsible for cost effectiveness for health expenditures}

From the almost second half of the 20th century, Public expenditure on health care has been increasing not only in absolute terms but also relative to the national incomes. This consistent growth was an outcome of profound economic, institutional, social, and technological changes that occurred all over the world. Which therefore led to an increase in public awareness, the expectations of stakeholders, and health care demand on one side, and on the other hand, the improvements in the medical field allowed them to offer better although expensive health care.

Health care expenditure is affected by a lot of factors, and their interaction is very complex to identify the exclusive outcome on health with health care expenditure increase of a particular form. With econometric tools, the impact of the respective variables on health care production and spending can be estimated. This is possible by using past observations, but the policymakers are interested in the explanatory power of such an exercise and its usefulness in anticipating future developments in the health care sector. The following are the main variables that are gathered from the literature considering their relationship with the effectiveness of Health Expenditures.

\subsection{Income}

In the literature, many factors are referred to as possible drivers for health care expenditures. But Income (per capita GDP) is considered as a very important factor for explaining differences across countries in the growth of health care expenditures. Some old studies like Newhouse (1977) generally used cross-sectional data to identify the determinants of health care expenses. They found income to be a crucial factor in the growth of health care expenditures in developed countries.

Milne and Molana (1991) also found that countries with the highest real per capita income have expensive health care. These found health care a luxury good. While Feldstein (1979) argues that the income elasticity of Health Care Expenditures is less than 1 which means the percentage increase in Health Expenditure is less than the percentage increase in income. This result may be because at that time per capita health expenditures were low. Hitiris and Posnett (1992) estimated individual country and for pooled cross-section and time series models, respectively, for OECD countries, found a strong positive relationship between Health Expenditures and GDP levels.

On the other hand, due to a lot of criticism on the cross-section data use and the latest estimation techniques in panel Data, several studies in OECD countries used panel data and found income elasticity larger than one (Gerdtham, Sogaard, et al.1992). Recently Baltagi and Moscone (2010) studied the long-run relationship between health expenditures and income for 20 OECD countries over the period 1971-2004. They found that health care expenditures and their determinants had a long-run relationship. They found health care elasticity concerning income which was about 0.87. Gerdtham and J"onnson (2000) studied the literature on international comparisons of health care expenditures and found that among other variables like aging, technology, and institutions, income is the most important variable. They conclude that the most crucial factor for the difference in health care expenditures is aggregate income. The effect of gross domestic product is positive and significant.

Therefore, from the above discussion role of aggregate income (GDP) in an increase in Health expenditure is found to one of the significant factors, and irrespective of the value the direction of the relationship appears to be positive.

\subsection{Technology}

Many studies find a significant positive effect of income on health care expenditures. However, Studies who overlook the influence of technological change may overestimate the income elasticity. Therefore, a proper econometric model linking health care expenditures with income should cover all other crucial factors and technology is one of them. In health care research, the effect increased use of medical technology on health care costs increases has always been a great unknown. But from the past few years' economists and researchers are interested in the investigation of the role of technology as a driver of Health Care Expenditures. Almost all economists agreed with the statement that "Over the past 30 years, the particular reason for the increase in the health sector's share of GDP is the technological change in medicine" Smith et al. (2000).

A paper by Congressional Budget Office (CBO) titled "Technological change and the growth of health spending" (2008), reviewed previous literature and concludes that at least $50 \%$ of the increase in health care costs is due to technological advancements. The broader literature estimates a range of $40-80 \%$ of technological Impact to increase Health Costs. Such results along with the perception that long-term projected growth in health care spending 
is unsustainable, have led some analysts to propose that measures like slowing the diffusion of expensive new technologies to control the health care costs. Given the importance of both health care and innovation to society's welfare, it is important to estimate this contribution at the highest precision possible.

Medical technology is the most important supply factor which affects the entire development, production, delivery, and financing process of health care. Whereas, the precise estimates of its contribution to the improvement in longevity and health status are still missing, while recent studies can link it to an ever more crucial role in the explanation of increased health expenditure. Technology is defined as the drugs (pharma-ceuticals and vaccines), medical tools, healthcare-related processes, congenial systems, and an authority that can link all the separate elements together which are responsible for health care cost increase. Newhouse (1992) quantified the consequences of technology, the study found that the majority of health care expenditure increase in the industrialized countries is attributable to the rapid changes in technology. After that many other studies, for example, Okunade and Murthy (2002) have supported Newhouse inference. More recently, Oliveira Martins and de la Maisonneuve (2005) found that over the last decades, health care spending has increased rapidly as compared to the aggregate income, the outcome of changes in technology, and the relative prices also significantly affected the health care cost increases.

However, from the methodology context, with lack of empirical data and having no common methodology for quantifying the outcome of changes in medical technology on health care expenditures; three methods (The first one called the Residual approach, second Proxy Approach, and third Case Studies analysis) has been utilized empirically to establish the total impact. You et al. (2016) investigated the relationship of Health Care Expenditure with income per capita and measures of technology in both the long and short-run in Australia for 39 years (1971-2011). It used both technology proxy and residual component approaches in the co-integration framework. Research and development spending, hospital research spending, two technology indexes constructed from medical devices, and infant mortality rate showed a firm long-run relationship with income and Health care expenditure. Further, income elasticities suggest that health care is a normal good and a technical necessity.

Okunade \& Murthy (2002) studied the role of R\&D expenditures (total and in the health sector) as interchangeable proxies for technical change in health care, as a major driver of increased health care costs in the US for the period of 1960-1997. Technology on the supply side while aggregate income on the demand side is hypothesized as the major determinants of increased health care costs. It used unit root and cointe-gration tests. The study found a stable economic relationship among US aggregate per capita health care expenditure, technological change, and income. which confirms the untested conjecture that changes in R\&D spending as a proxy for change in technology, is a significant driver of rising health care expenditure. Whereas Newhouse (1992) suggested technological progress as another major factor accounting for as much as $75 \%$ of the 50 years increase in US medical care expenses.

Joseph Newhouse's (1992 \& 1993) papers are main contributions in the investigation of the macroeconomic approach to estimate the contribution of the factors to health spending growth and assume the unexplained residual growth is attributed to technology. He found that if technology had been constant then income growth, demographics changes, and insurance growth would have accounted for "well under half-perhaps under a quarter" of the increase in medical care spending in the period 1940-1990.

Smith et al. (2009) found that increased medical technology is the primary driver of health spending growth. But technology doesn't expand independently, it is fueled by rising incomes and insurance coverage. Medical technology explains 27-48 percent of health spending growth since 1960 in the US.

The flow of technological services from R\&D activities have positive and direct effects on innovation as output (Acs and Audretsch,1988). Technologies in the medical sector have generally emerged from private and public R\&D efforts and other kinds of collaborations. Collaborative alliances in the innovation process within and outside of industries are very important (Arora and Gambardella,1994). Partnerships of Industries and universities in medical research have also played a huge part in the innovations of drugs, optics, and nuclear technologies, etc. (Jaffe,1989).

Smith et al. (2000) reviewed the past literature and estimated the approximate range for the contribution of technological change to growth in health spending. It used the existing macroeconomic residual-based estimates and concluded that technological change is the major reason behind the invariable increase in the health share of the GDP. It found a range of 38 to 62 percent of the total growth in real per capita income. It also suggested that in the absence of technological change, growth in the real per capita health spending for 1940-98 would have averaged about $2.5 \%$ per year, only slightly higher than growth in real per capita GDP (near 2.0\%). 
Metz (2012) estimated an upper bound for the contribution of technological progress on health care costs by using US time series data. He follows the model of the Congressional Budget Office's (CBO) 2008 report and uses the identical data.

He found that the contribution of technological progress is $32.3 \%$, which is smaller than suggested by CBO's report that was $50 \%$.

Dybczak \& Przywara (2010) used the data for European economies to estimate the expected impact of technological progress on health care expenditures. Single OLS and fixed effect regressions have been estimated at the individual country level and pooled data. It found that technology in health care has a relevant contribution to improving health status and extending life expectancy.

So, from the above brief review, the role of technology is found to be positive in health costs increase. However, since the improvement in technology leads to better health outcomes as well so it because of a question of cost and benefit and requires further inquiry. But overall literature review reveals that technological development in the health care sector has been affecting the cost significantly.

\subsection{Institutional quality}

Health outcomes and Health spending linkage have been evaluated all around the world with different approaches. These studies have found that the linkage is insignificant for countries that have institutional issues that can be fully sight seen. Imperfect research and data complicate in designing effective policies, but evidence on the nature of health institutions has begun to emerge. Poor quality Institutions caused severe restrictions on improving health through the conveyance of health care services in developing countries.

Health care access has considerably improved in the last two decades, and contrary to that the health outcomes have not improved by the same proportion, thus reflecting saturation in this sector. One of the major reasons identified in the recent literature is the considerable non-existence of accountability and less motivation for desired outcomes (Lewis 2006). This primarily reflects the inability of the government or the ineffectiveness "government interventions that have gone wrong" (Jack and Lewis, 2004).

Another issue as per the review of literature is that although the quality of an institution is a well-researched theme specifically for the health sector it's not that much well researched. Investment in the health sector is being made but due to lack of the health institutions' quality, these are not resulting in a significant relationship with health outcomes. As a result, vital health statistics and especially those which are helpful in effective planning such as utilization statistics, hospital infection rates, or surgery survival rates are not collected owing to weak regulation and enforcement in poor and middle-income countries (Lewis 2006). There are some other relevant variables as well which can undermine effective service delivery such as provider absenteeism, poor management, funds leakage, and lack of medical supplies. Therefore, to have better health outcomes focus should not only be on more investment in health care but rather the quality of institutions should also be considered. Till that time the relationship between the Health care expenditures and the Health outcomes will remain weak.

Rizvi (2019) determines the effect of health expenditures on economic growth considering the quality of health institutions with the hypothesis that where institutions are a better investment in health brings more economic growth as compared to the institution having weaker governance institutions. The study reveals that if Health expenditures are augmented for the Quality of Government Expenditures then a 100 percent increase in Health Expenditure would lead to a Five percent increase in overall Economic Growth.

Further, Health expenditures have been researched well in the literature but the quality of these investments and the quality of institutions involved in these are not that much researched. Whereas it's now established that besides the level it's the quality and soundness of the institutions which play a major role in achieving the growth targets. Although the role of institutions in economic growth has been established. How- ever little attention has been given on its application such as Health Care expenditures and health outcomes. There is some evidence but not many studies could be found. Seeing this in this paper we will discuss some evidence on this topic and the significance of institutional firming to improve health status besides the level of health care expenditures.

\subsection{Health Insurance}

Insurance coverage is strongly related to better health outcomes for both children and adults as it makes health care affordable and helps consumers use care appropriately. Insurance improves health outcomes by helping people 
obtain preventive and screening services, prescription drug benefits, mental health, and other services, and by improving continuity of care. Vulnerable populations are especially at risk of poor health outcomes when they are uninsured. Insurance coverage can also improve social and economic well-being, by averting developmental problems in children, increasing workforce productivity, decreasing the use of hospital services, and reducing costs of public programs. Over the last few years, health insurance has taken as prominent a spot in national politics in both developed and developing countries.

There is extensive literature on the influence of health insurance systems in developed countries. Evidence has shown that health insurance coverage is associated with better self-reported health status and lower mortality risk (Franks et al., 1993; McWilliams et al., 2004; Hadley and Waidmann, 2006). These findings are limited, however, by concerns about selection biases inherent in these observational studies. Few of the recent studies have also explored the causal linking between Insurance in Health and Health Outcomes. For these, they have used the Public Health Insurance as a natural experiment. But it has provided mixed results. One of the instances studies showed that with the Health program Medicaid in USA mothers had better access to prenatal care and for children utilization of preventive care improved. Which resulted in the reduction of infant mortality and low birth weight issue for children. However, it did not result in an improvement in the health status of older children (Currie and Gruber, 1996a, 1996b, 1997; Currie et al., 2008). On the other side studies on the elderly population of the US spells out that the enhancement of coverage in health insurance through Medicare for the older people of age 65 has resulted in more use of medical care and improved self-reported health status, and lesser out-of-pocket expenses but has little effect on mortality (Decker and Remler, 2004; Card et al., 2008; Finkelstein and McKnight, 2008). Studies on Taiwan find that the introduction of the National Health Insurance program has reduced mortality for infants (Chou et al., 2011), but the results for the elderly are mixed (Chen et al., 2007; Chang, 2012; Keng and Sheu, 2013).

Unfortunately, such studies cannot be found much for developing countries, although these countries have been trying to institute or extend domestic public health insurance programs in the recent past, and one such case is of China. There are some studies which have evaluated the public health insurance of Vietnam (Jowett et al., 2004; Sepehri et al., 2006), Colombia (Panopoulu and Velez, 2001; Trujillo et al., 2005), and of Mexico (Gakidou et al., 2006). Further, there are also two such earlier studies on the impact of local efforts to improve community health insurance in rural China even before the initiation of the NCMS. One such study is of Wang et al. (2009), where they show that the community-based health insurance scheme increased the health status of members in one of China's western provinces. There is another study, by Wagstaff and Yu (2007), which considers a reform project from the demand and supply sides both of the rural health sector in Gansu province of China and concludes that it relaxed the financial crunch on individual households, however, it did not affect health care utilization and there were mixed effects on the health outcomes.

Chen and Jin (2011) investigated the effects of the introduction of the New Cooperative Medical System (NCMS) on child mortality, maternal mortality, and school enrollment. The study used the data for 5.9 million people living in eight low-income rural countries. Raw data suggested that NCMS showed positive results with reduced child and mother mortality and better education outcomes. While the difference-in-difference propensity score matching suggested that NCMS did not affect the child and mother mortality but improved school enrollment.

Fink et al. (2013) analyzed the community-based insurance scheme rolled out in Nouna District, Burkina Faso between 2004 and 2006. The study identified the causal effects of health insurance on population-level mortality and household level health as well as welfare outcomes. The study found that insurance has some positive effects on health expenditure but found no improvement for children and working-age results, and astonishingly, negative health effects of insurance on individuals age 65 and older.

Lipton and Decker (2015) analyzed the effect of Medicaid coverage of vision services for adults using data from 2002-2013 NHIS, a continuous cross-sectional survey of the civilian, non-institutionalized population of the United States conducted by the Centers for Disease Control and Prevention's National Center for Health Statistics (NCHS). The study examined the effect of vision insurance on eye care uses and vision health outcomes by using quasiexperimental variations in Medicaid coverage for adult vision care. They used the difference-in-difference approach and found that Medicaid beneficiaries with vision coverage are $4.4 \%$ more likely to have seen an eye doctor, 5.3\% lesser chances for needing but did not opt to buy eyeglasses due to the expense, $2.0 \%$ lesser chances for reporting 
CCenter for Promoting Education and Research (CPER) USA,www.cpernet.org

difficulty in seeing with the normal vision correction and $1.2 \%$ lesser chances for having a functional restriction due to the vision.

Financing for risk coverage is very important. In this case, since health expenditures are contingent, buying insurance would yield different behavior as compared to no holders. From the above discussion, it appears that insurance coverage does help in improving health outcomes. However, it will have a bearing on cost as well, which needs to be explored further.

\subsection{Preventive Healthcare}

\subsubsection{Education}

It is a fact that people with higher levels of education are more likely to be at work and if they have a job, are paid more than those with low-level education. People with more education and thus higher incomes have a lower risk of stress and diseases that are associated with social and economic hardships. While those with less education have less knowledge and resources to avoid the effects of stress. Economic hardships, trauma, and stress can harm health over time and make individuals more sensitive to further stressors.

Education has a direct effect on health and healthy behaviors because people learn about the effects of unhealthy behaviors at school, college, or university. Besides, educated people can better understand the basic consequences of unhealthy living. And also, indirectly better education helps in securing higher-paying jobs, and consequently educated people can afford the things that help them to live a healthier lifestyle. People having a good job with high income can lower the stress risk and more educated people usually work in safer environments.

Mary Silles(2009), found evidence of a causal relationship between education and health, in case of an increased year of education increases the probability for 'good' health by about 4 to 6 percent. She also suggests that the probability of having no long-standing illness shot up by 5 to 7 percent and the probability of having no work-preventing illness shot up by about 1 percent.

Cutler and Lleras-Muney (2007) reviewed the literature and analyzed the relationship between education and health. They found a clear association between education and health. The study found that better-educated people have lower morbidity rates. Similarly, it found that life expectancy is increasing for everyone in the United States, thus differences in life expectancy have grown over time between those with and without a college education.

\subsubsection{Behavior}

Apart from better jobs, people with more education are more likely to learn about healthy behaviors. For example, educated patients can better understand their health conditions, follow instructions, and interact effectively with their health care providers.

Educated people can learn more about health and health risks and are more receptive to health education campaigns. Education not only helps to make happy and healthy lifestyle choices but also to better skills and greater self-advocacy. Education improves skills such as literacy, develops effective habits, and may improve cognitive ability. Also, people with lower health literacy are less likely to use preventive services and take medications. Among the elderly, poor health literacy has been associated with poorer health status and higher death rates.

Also, Educated people focus on their future life outcomes which make them less likely to participate in unhealthy behaviors like smoking and drinking. If more educated people tend to work and socialize with others, then peer effects can play a huge part because a person can more likely to follow his/her neighbor's or colleague's healthy lifestyle.

\subsubsection{Summary and research gap}

Indeed, Income and technology both are significant drivers of health care expenditure. It is hard to spend more on new medical technology, without an increase in income but without modern technology in the end there will be no reason to want more health care per capita. But, the effect of education is significant in many recent studies. Despite the positive effects of health insurance on health outcomes it also seems to increase health care expenditures over time. Nevertheless, institutional quality matters the most in the working of health care institutions and the delivery of health care services. Hence, this paper aims to contribute to the existing literature by investigating the determinants of health care expenditures in an empirical analysis. 
The first purpose of this paper was to give an up-to-date overview of the literate on the factors responsible for the growth of health care expenditures in developed and developing countries. From the above, we conclude that income, technology, institutional quality, education, and health insurances are important in explaining health care expenditure growth. Secondly, this paper tries to contribute to the existing literature by examining the effect of the above-mentioned factors on health care expenditures through empirical analysis using static and dynamic models for developed and developing countries.

\section{Model and Econometric Methods}

At the macro expenditure-outcome frontier some countries are spending relatively more i.e. these are expensive, and the issue to be seen is why? In that context one of the theories is the nature of this service, cause-effects are not one-to-one, so over time health technology usage and defensive medicine use are on the higher side. Second, if there is legislation where in case of an improper treatment the patient can sue back for incompetent treatment, this can force the doctor to prescribe more drugs and test and the overall treatment becomes more expensive. Third, in countries in which old age people are proportionally more than the health care expenditures are more as compared to the countries in which the younger generation is more. So, it would be beneficial to bifurcate the data such as Developing and developed countries because the underlying factors may vary across this segregation. Secondly to verify these potential determinants we need to run the regression with the variables discussed earlier. This may be done by including a dummy for developing and developed countries as an additional variable.

We started with a standard static fixed and random effects panel model (Table A3 in appendix) by using a natural log of health expenditures per capita as dependent variables and independent variables explained above for both developing and developed countries sample.

\section{Static Model: Health Expenditures per capita (PPP) as the dependent variable:}

$$
\begin{gathered}
\ln \left(H E P P P_{i t}\right)=\beta_{i t}+\beta_{\mathbf{1}} \ln \left(G D P_{i t}\right)+\beta_{\mathbf{2}} \ln \left(G E_{i t}\right)+\beta_{\mathbf{3}} R D_{i t}+\beta_{\mathbf{4}} P R I E D U_{i t} \\
+\beta_{\mathbf{5}} S S_{i t}+\beta_{\mathbf{6}} P R I V I N S_{i t}+\beta_{\mathbf{7}} G F C F_{i t}+\beta_{\mathbf{8}} P G_{i t}+s_{i t}
\end{gathered}
$$

In the model, we have used health expenditures per capita in PPP terms as a dependent variable. The reason for taking this variable is that naturally the level of health expenditures could not be compared directly, second owing to the difference in prices again may not reflect the actual differences. So, the overall model will help us determine the significance and relative importance of variables which increases the per capita expenditures across countries.

Where, $\mathrm{t}=$ time period (1996-2014), $\mathrm{i}=$ number of countries, $\ln ($ HEPPP $)$ is the health expenditures per capita in PPP (natural log), $\ln ($ GDP ) is GDP per capita in natural $\log , \ln (\mathrm{GE})$ is government effectiveness in natural log, RD is Research and Development expenditure, PRIEDU is primary Education completion, SS is social security funds, , PRIVINS is Private insurance Payments, GFCF is gross fixed capital formation and PG is the population growth

\section{Dynamic Model: Health Expenditures per capita (PPP) as dependent variable:}

$$
\begin{aligned}
\ln \left(H E P P P_{i t}\right)= & \beta_{i t}+\beta_{\mathbf{1}} \ln \left(G D P_{i t}\right)+\beta_{\mathbf{2}} \ln \left(G E_{i t}\right)+\beta_{\mathbf{3}} R D_{i t}+\beta_{\mathbf{4}} P R I E D U_{i t}+\beta_{\mathbf{5}} S S_{i t} \\
& +\beta_{\mathbf{6}} P R I V I N S_{i t}+\beta_{\mathbf{7}} G F C F_{i t}+\beta_{\mathbf{8}} P G_{i t}+\ln \left(H E P P P_{i t-1}\right)+s_{i t}
\end{aligned}
$$

We also specified a dynamic relationship that is characterized by the presence of a lagged dependent variable among the repressor's. For estimating these models, we have used the econometric models for Panel data sets i.e. Fixed/Random Effects and a System GMM for both data sets.

\section{Data and Variables}

\subsection{Variables}

Here we will explain the variables used for empirical estimation.

Dependent Variables: For regression purposes, we have taken Health expenditures per capita (PPP) (in natural $\log$ ) as the dependent variable. As stated above the reason for taking that was to make our results comparable across countries.

Independent Variables: Independent variables are population growth; Since the study is on a macro level, so increase in population would increase pressure on existing resources at the same time being per capita in nature it may reduce the expenditures made per capita, Primary education completion; this is the variable taken especially from the 
context of higher education leading to higher incomes as explained in literature review, increasing awareness thus acting both increase in preventive methods or behavioral for health outcomes and accessing health care services more feeling the need, R\&D; increase in R\&D can lead to more and sophisticated equipment's availability which may result in higher cost, natural log of government effectiveness; this is an important variable of our study as our hypothesis claims that less efficient government can lead to higher expenditure requirements thus increasing the cost of Health Care utilization, natural log of GDP per capita; this is the standard income proxy variable and we expect this sign to be positively related to the dependent variable, gross fixed capital formation; since model is a Quasi Solow growth model hence for model completion this variable is taken, government social security funds; this is an indicator for government subsidy to the poorest segment of the society the labor class and private prepaid insurance plans; this variable is the insurance holding penetration variable.

Instrumental variable: To deal with potential endogeneity, this study uses $\ln (G D P)$ per capita and Social Security funds as internal instruments in the system GMM.

\subsection{Data}

Most of the data is taken from World Bank-World Development Indicators (WDI) of 133 developing and 36 developed countries for the past 19 years (1996-2014). The variables include health expenditures per capita (PPP), population growth, Primary education completion (proxied for preventive health care), R\&D (proxied for technology), government effectiveness (in natural log) (proxied for quality of institutions), GDP per capita (in natural log), gross fixed capital formation. While data for government social security funds ${ }^{1}$ and private prepaid insurance plans ${ }^{2}$ is taken from the World Health Organization (WHO). Descriptive statistics are provided in the appendix (Table A1).

\section{Regression Results}

To see first, the structural difference in the two data sets with regards to the health expenditures we ran a simple OLS model (Table A2 in Appendix). It appeared that the dummy was highly significant. This means splitting the data into two sets (developing and developed) will be beneficial. Hence in the second step, we ran both static and dynamic panel models for the developing and developed country's data sets separately. In the third step selection of random or fixed model was based on the Hausman specification test and the Fixed effect model was selected. Below we will present the results of these model estimations.

\subsection{Developed countries results (Table A3 in appendix)}

From our results in the case of Developed countries, GDP was found to be significant and positively associated with the health expenditures in both static and dynamic models (1.826 and 0.383), This means that Income is the major driver for the rise in the health expenditures overtime for the developed countries. People tend to spend more as they get wealthier. However, the static and Dynamic model coefficient is different. For the Dynamic model, the co-efficient is smaller although positive. This shows that in the long run since it's the other variables that take away the impact which in the static model is more attributed to income. Second Government effectiveness was also found to be significant in the static model only although it is negatively related to the health expenditures in both static and dynamic models. Its co-efficient value is -0.635 , which shows that it does reduce the Health expenditures required for the same level of health improvement. This could be both from the context of government own expenditures being more effective as well as through improved regulatory environment affordable health care is provided. Because countries with good institutions quality and less corruption will have less health expenditure with suitable outcomes. Whereas, research and development expenditures were significant and positively associated with health expenditures in both static and dynamic models (0.14 and 0.076) as it is quite evident from the literature also that technology triggers health expenditures through an increase in the availability of more sophisticated technologies as well as improved generation of medicines and tests. Primary education was significant and negatively related to health expenditures in long run (0.008) because educated people can better understand their health conditions and make expenditures accordingly as well as the move to more preventive discourse. People learn about the effects of unhealthy behaviors at school, college, or university. Besides, educated people can better understand the basic consequences of unhealthy living and hence less unhealthy diet/behavior and disease incidence will lead to less total health expenditures. Whereas in the Static

\footnotetext{
${ }^{1}$ Data retrieved from http://apps.who.int/gho/data/node.wrapper.imr? $\mathrm{x}-\mathrm{id}=121$

2 Data retrieved from http://apps.who.int/gho/data/node.wrapper.imr?x-id=120
} 
model it is positively and significantly related to health expenditures (.001). This shows that in the short term with increase education people would tend to start accessing health care services more. Although the co-efficient is much lower as compared to the earlier variables being discussed. Social security funds and private insurance payments were significantly and negatively related to the dependent variable in the long run $(-0.009$ and -.031$)$. This means with improved Social security funds people are provided with necessary resources which helps them improve their living standards and behavior thus creating lesser chances of getting sick. On the other hand, the negative association of the insurance plans with health expenditures shows that people with health plans will have more health care utilization as they are insured hence reducing the potential higher expenditures in case of non-managed diseases. In the case of shortrun relationships Social Security fund has the same relation however with Private Insurance payments it's positively significantly related. This could be because initially people are not adapted to the use of insurance plans more effectively as well as the upfront payments are higher in most of the Health insurance plans (-.005 and .004). Other control variables show standard signs in the dynamic model.

\subsection{Developing countries results (Table A3 in appendix)}

In contrast to the first group of countries, the outcomes for the second group are a bit different thus showing the importance of tailor-making in policies when donors approach developing countries for assistance related to the Health Sector. GDP was found positively associated with health expenditures both in the short and long run but was significant in the static model only (1.895). The coefficient of GDP was also not very different from developed countries. This shows that in either case, higher income leads to the same behavior across the two data sets. While government effectiveness is found significant and positively related to health expenditures in both the short and long run $(0.63$, 0.819). This is the opposite of the developed country case. One of the possible reasons is that government effectiveness for countries with low health outcomes would first increase in health expenditures per capita. This is because these developing countries are far behind in health outcomes as compared to the developed countries and they need to do a catching up. So a better governance system will help countries invest more in their Human capital development. Like developed countries, the same is the case for Research and Development expenditures, which are found positively related to the dependent variable but significant in the short-run only (0.193). This shows that better health technologies put pressure on health service utilization costs in the short run. One of the reasons for not significant results, in the long run, is the low levels of $R \& D$, hence programs with insufficient funding could not generate the same effects in the long run which for developing countries is positive and significant. Whereas, Primary Education completion was found to be positively related to health expenditures but significant in long run only (0.003). Unlike the developed countries even in the long run, educated members of society tend to spend higher as preventive health care systems are not that prevalent in the developing countries. These are not included in the syllabi and other potential instruments of mass awareness at the primary level of education. Social Security funds are found to be negatively related to health expenditure in static (-0.004), while positively associated in long run but significant in the short run only. Social security funds are mainly provided in terms of health care services and pensions in developing countries. So, in a sense, the help people maintain better life standards and keep catastrophic health expenditures low. Unlike the developing country's case, the Private Insurance Plan is negatively related to the dependent variable in both the short and long run but significant in the short-run only (-0.003). This shows that with insurance fund enrollment people tend to save more as compared to the contributions. One of the justifications provided often is that the Health insurer acts like an agent who is more informed about the actual cost and requirements of the treatment hence can save extra cost which is usually occurred due to the asymmetric information and induced demand behavior of health sector caregivers in developing countries. However, in the long run, the usual benefits of Health insurance funds are not that effective due to the low penetration of this sector.

\section{Discussion and Conclusions}

\subsection{Conclusion}

There are massive Health Challenges across the globe with varying nature and complexities. However, it has been well recognized e.g. out of the Eight MDGs three focused on health. Even in the new frameworks of development like the SDGs, these are given extreme importance. SDG 3 directly talks about health and all other goals are indirectly linked to better health. Countries across the globe are increasing expenditures to improve outcome performance but outcomes are not the same. Some are more efficient some less. Considering the importance of these product ivy differences it becomes essential to see the drivers of health expenditures across countries. 
The study took two data sets, one from the developing countries and second of developed countries as per World Bank classification. As anticipated, there are i. significant differences in the health per capita expenditures. Thus, making two data sets non-comparable. ii. Determinants were also found to behave differently both in the short run and long run as well as across the two data sets. Income levels mattered the most in case of higher levels of health care expenditures. Government effectiveness for developed countries meant efficiency in terms of lesser expenditure requirements whereas for developing countries it can help achieve the desired levels of expenditures. The same was the case for primary education as a proxy of the basic level of education. Improved technology leads to the increased cost of health care utilization across the board. Developed countries having almost fully health-insured societies have efficient outcomes but for developing countries outcomes are also not bad. As in developing countries case, the insurance sector acts as an agent to avoid asymmetric information phenomenon which in the case of health care demand is more prevalent as induced demand.

\subsection{Limitations of the study}

Since some variables were proxy to the best possible extent hence results may improve more if purpose-built data is collected. Second, in most of the developing countries data on health care expenditures are collected through the survey so usual limitations to these hold. The Rest data set used is a time-series data and usual limitations may apply.

\subsection{Policy implications}

To achieve SDG targets related to health outcomes governments need to increase resource allocation as well as identify means for better, equitable, and affordable Health Care Systems. Having said that policy options for developing countries will be different from the policy prescriptions of developed countries. For developed countries focus may be more on tapping on an increase in cost whereas for developing countries it's the level of resource allocation and improvement in the system such as better curriculum for preventive health care, insurance sector development, etc.

\section{References}

Abrantes-Metz, R. M. (2012). The Contribution of Innovation to Health Care Costs: At Least 50\%?.

Akram, N.; Padda, I. \& Khan, M. (2008), The long term impact of health on economic growth in Pakistan. The Pakistan Development Review, 487-500.

Ashraf, Q.; Lester, A; \& Weil, D. (2008), When does improving health raise GDP. National Bureau of Economic Research, Working paper, 14449.

Baltagi, B. H., \& Moscone, F. (2010). Health care expenditure and income in the OECD reconsidered: Evidence from panel data. Economic Modelling, 27(4), 804-811.

Bernstein, J., Chollet, D., \& Peterson, S. (2010). How does insurance coverage improve health outcomes. Mathe- matica Policy Research, Inc, 1, 1-10.

Bloom, D.; Canning, D. \& Sevilla, J. (2001), The effect of Health on Economic Growth: Theory and Evidence. NBER working Paper, 8587.

Boachie, M. (2015), Effect of health on economic growth in Ghana: an application of ARDL bounds test to cointegration. MPRA, 67201.

Card D, Dobkin C, Maestas N. 2008. The impact of nearly universal insurance coverage on health care utilization and health: evidence from Medicare. American Economic Review 98(5): 2242-2258.

Cardella, E., \& Depew, B. (2014). The effect of health insurance coverage on the reported health of young adults. Economics Letters, 124(3), 406-410.

Chaudhary et al. (2005), Missing in action: teacher and health worker absence in developing countries. Journal of Economic Perspectives, 91-116.

Chen, Y., \& Jin, G. Z. (2012). Does health insurance coverage lead to better health and educational outcomes?

Evidence from rural China. Journal of health economics, 31(1), 1-14. 
Cheng, L., Liu, H., Zhang, Y., Shen, K., \& Zeng, Y. (2015). The impact of health insurance on health outcomes and spending of the elderly: evidence from China's New Cooperative Medical Scheme. Health economics, 24(6), 672-691. Commission Staff Working Document (2013), Investing in health.

Cullis, J. \& West, P. (1979), The economics of health : an introduction, Oxford , MA: Martin Ribertson, 84-9. Culyer, A. \& Newhouse,J. (2000), Hand Book of health Economics.

Currie J, Decker S, Lin W. 2008. Has public health insurance for older children reduced disparities in access to care and health outcomes? Journal of Health Economics 27(6): 1567-1581.

Currie J, Gruber J. 1996a. Health insurance eligibility, utilization of medical care and child health. Quarterly Journal of Economics 111(2): 431-466.

Currie J, Gruber J. 1996b. Saving babies: the efficacy and cost of recent changes in the Medicaid eligibility of pregnant women. Journal of Political Economy 104(6): 1263-1296.

Currie J, Gruber J. 1997. The technology of birth: health insurance, medical interventions and infant health. Working Paper 5985, National Bureau Economic Research, Cambridge, MA.

Decker SL, Remler DK. 2004. How much might universal health insurance reduce socioeconomic disparities in health? A comparison of the US and Canada. Applied Health Economics and Health Policy 3(4): 205-216.

Dybczak, K., \& Przywara, B. (2010). The role of technology in health care expenditure in the EU (No. 400).

Directorate General Economic and Financial Affairs (DG ECFIN), European Commission.

Evans, D. B., Tandon, A., Murray, C. J., \& Lauer, J. A. (2000). The comparative efficiency of national health systems in producing health: an analysis of 191 countries. Geneva: World Health Organization.

Feldstein PJ (1979) Health care economics. Wiley: New York

Fink, G., Robyn, P. J., Si'e, A., \& Sauerborn, R. (2013). Does health insurance improve health?: Evidence from a randomized community-based insurance rollout in rural Burkina Faso. Journal of health economics, 32(6), 1043-1056.

Finkelstein A, McKnight R. 2008. What did Medicare do? The initial impact of Medicare on mortality and out of pocket medical spending. Journal of Public Economics 92(7): 1644-1668.

Franks P, Clancy C, Gold MR, Nutting PA. 1993. Health insurance and subjective health status: data from the 1987 National Medical Expenditure Survey. American Journal of Public Health 83(9): 1295-1299.

Gakidou E, Lozano R, Gonzalez-Pier E, Abbott-Klafter J, Barofsky JT, Bryson-Cahn C, Feehan DM, Lee DK, HernandezLlamas H, Murray CJ. 2006. Assessing the effect of the 2001-06 Mexican health reform: an interim report card. The Lancet 368(9550): 1920-1935.

Hadley J, Waidmann T. 2006. Health insurance and health at age 65: implications for medical care spending on new Medicare beneficiaries. Health Services Research 41(2): 429-451.

Hitiris, T. (1997). Health care expenditure and integration in the countries of the European Union. Applied Economics, 29(1), 1-6.

Hitiris, T., \& Posnett, J. (1992). The determinants and effects of health expenditure in developed countries. Journal of health economics, 11(2), 173-181.

Holly, A., Ke, X., \& Saksena, P. (2011). The Determinants of Health Expenditure: A Country-Level Panel Data Analysis. World Health Organisation Working Paper.

Jack, W. \& Lewis, M. (2009), Health investment and economic growth, macroeconomic evidence and microeco- nomic foundations. The World Bank, Development economics Vice Presidency, 4877.

Jewell, T., Lee, J., Tieslau, M., \& Strazicich, M. C. (2003). Stationarity of health expenditures and GDP: evidence from panel unit root tests with heterogeneous structural breaks. Journal of Health Economics, 22(2), 313-323.

J“onsson, B. \& Eckerlund, I. (2003), Why do different countries spend different amounts on health care?

Jowett M,Deolalikar A, MartinssonP. 2004. Health insurance and treatment seeking behavior: evidence from a lowincome country. Health Economics 13(9): 845-857 
Kelly, M. (2017). Health capital accumulation, health insurance, and aggregate outcomes: A neoclassical approach. Journal of Macroeconomics, 52, 1-22.

Keng S, Sheu S. 2013. The effect of national health insurance on mortality and the SES-health gradient: evidence from the elderly in Taiwan. Health Economics 22(1): 52-72.

Kiymaz, H., Akbulut, Y., \& Demir, A. (2006). Tests of stationarity and cointegration of health care expenditure and gross domestic product. The European Journal of Health Economics, 7(4), 285-289.

Kruk, M. E., \& Freedman, L. P. (2008).

Assessing health system performance in developing countries: a review of the literature. Health policy, 85(3), 263-276. Makinen, M., Waters, H., Rauch, M., Almagambetova, N., Bitr’an, R., Gilson, L., ... \& Ram, S. (2000). Inequalities in health care use and expenditures: empirical data from eight developing countries and countries in transition. Bulletin of the World Health Organization, 78(1), 55-65.

Malik, G. (2006), An examination of the relationship between health and economic growth. ICRIER Working Paper, 185. Martins, J. O., De la Maisonneuve, C., \& Bjornerud, S. (2006, March). Projections of OECD health and long-term care public expenditures. In Proceedings of the Public Finance Workshop, Perugia (Vol. 30).

McWilliams JM, Zaslavsky AM, Meara E, Ayanian JZ. 2004. Health insurance coverage and mortality among the nearelderly. Health Affairs 23(4): 223-233.

Milne, R., \& Molana, H. (1991). On the effect of income and relative price on demand for health care: EC evidence. Applied Economics, 23(7), 1221-1226.

Narayan, S.; Narayan, P. \& Mishra, S. (2010), Investigating the relationship between health and economic growth: empirical evidence from a panel of 5 Asian countries. Journal of Asian Economies, 404-411.

Newhouse, J. P. (1977). Medical-care expenditure: a cross-national survey. The Journal of Human Resources, 12(1), 115-125.

OECD (2015), Health Expenditure in relation to GDP, in health at a glance 2015.OECD Indicators.

Okunade, A. A., \& Murthy, V. N. (2002). Technology as a 'major driver'of health care costs: a cointegration analysis of the Newhouse conjecture. Journal of health economics, 21(1), 147-159.

Panopoulu G, Velez C. 2001. Subsidized health insurance, proxy means testing and the demand for health care among the poor in Colombia. Colombia Poverty Report Volume II. Washington DC, World Bank.

Poullier, J. P., Hernandez, P., Kawabata, K., \& Savedoff, W. D. (2002). Patterns of global health expenditures: results for 191 countries. Geneva: World Health Organization.

Pritchett,L. \& Summers, L.H. (1996), Wealthier is healthier. The Journal of Human Resources, 841-68. Reinhardt, U. E., Hussey, P. S., \& Anderson, G. F. (2002). Cross-national comparisons of health systems using OECD data, 1999. Health affairs, 21(3), 169-181.

Rivera, B. \& Currais, L. (1999), Income variation and health expenditure: evidence for OECD countries. Review of Development Economics, 3(3), 258-267.

Rivera, B. \& Currais, L. (2003), The effect of health investment on growth: a causality analysis. IAER, 312-323. Rizvi, S. A. F. (2019). Health Expenditures, Institutional Quality and Economic Growth. Health, 2(1), 63-82.

Scheffler, R.M. (2004), Health Expenditure and economic growth: an international perspective. Occasional Papers on Globalization, University of South Florida.

Schieber, G. J., Poullier, J. P., \& Greenwald, L. M. (1992). US health expenditure performance: an international comparison and data update. Health Care Financing Review, 13(4), 1.

Schreyer, P. (2010). Towards measuring the volume output of education and health services: A handbook. OECD Statistics Working Papers, 2010(2), 0*1.

Sepehri A, Sarma S, Simpson W. 2006. Does non-profit health insurance reduce financial burden? Evidence from the Vietnam Living Standards Survey Panel. Health Economics 15(6): 603-616. 
Siddiqui, R., Afridi, U., Haq, R., \& Tirmazi, S. H. (1995). Determinants of Expenditure on Health in Pakistan [with Comments]. The Pakistan development review, 34(4), 959-970.

Smith, S. D., Heffler, S. K., \& Freeland, M. S. (2000). The impact of technological change on health care cost spending: An evaluation of the literature. Health Care Financing Administration Health Care Financing Adminis- tration.

Smith, S., Newhouse, J. P., \& Freeland, M. S. (2009). Income, insurance, and technology: why does health spending outpace economic growth?. Health Affairs, 28(5), 1276-1284.

Tandon, A., Murray, C. J., Lauer, J. A., \& Evans, D. B. (2000). Measuring overall health system performance for 191 countries. Geneva: World Health Organization.

Travis, P., Bennett, S., Haines, A., Pang, T., Bhutta, Z., Hyder, A. A., ... \& Evans, T. (2004). Overcoming healthsystems constraints to achieve the Millennium Development Goals. The Lancet, 364(9437), 900-906.

Trujillo AJ, Portillo JE, Vernon JA. 2005. The impact of subsidized health insurance for the poor: evaluating the Colombian experience using propensity score matching. International Journal of Health Care Finance and Economics 5(3): 211-239.

Van Elk, R., Mot, E., \& Franses, P. H. (2010). Modeling healthcare expenditures: overview of the literature and evidence from a panel time-series model. Expert review of pharmacoeconomics \& outcomes research. Wagstaff A, Yu S. 2007. Do health sector reforms have their intended impacts?

The World Bank's Health VIII project in Gansu province, China. Journal of Health Economics 26(3): 505-535

Wallace, J., \& Sommers, B. D. (2016). Health Insurance Effects on Preventive Care and Health: A Methodologic Review. American journal of preventive medicine, 50(5), S27-S33.

Wang H, Yip W, Zhang L, Hsiao WC. 2009.

The impact of rural mutual health care on health status: evaluation of a social experiment in rural China. Health Economics 18(S2): S65-S82.

Why Education Matters to Health: Exploring the Causes, Issue Brief April 2014.

World Health Organization. (2012). Research and development to meet health needs in developing countries: strengthening global financing and coordination.

Xu, K., Evans, D. B., Kawabata, K., Zeramdini, R., Klavus, J., \& Murray, C. J. (2003). Household catastrophic health expenditure: a multicountry analysis. The lancet, 362(9378), 111-117.

You, X., \& Okunade, A. A. (2016). Income and Technology as Drivers of Australian Healthcare Expenditures. Health Economics. 
E-ISSN: 2471-7576

September 2020, Vol: 5, Issue: 9

E-mail: editor@ijhassnet.com

http://ijhassnet.com/

DOI: 10.33642/ijhass.v5n9p3

(C)enter for Promoting Education and Research (CPER) USA,www.cpernet.org

\section{Appendix}

\section{Table A1: Descriptive statistics}

\begin{tabular}{|c|c|c|c|c|c|c|c|c|}
\hline Variables & Symbol & Mean & Max & Min & Std.Dev & Observations & Source & Measuring unit \\
\hline Health expenditure & $\ln (H E P P P)$ & 5.935 & 9.148 & 1.274 & 1.406 & 3211 & WDI & $\begin{array}{l}\text { Purchasing power parity } \\
\text { constant } 2011\end{array}$ \\
\hline per capita & PG & 1.541 & 50.645 & -3.82 & 1.867 & 3190 & WDI & $\begin{array}{l}\text { international \$ Annual } \\
\text { percentage }\end{array}$ \\
\hline \multirow{2}{*}{$\begin{array}{l}\text { Population growth } \\
\text { Primary education } \\
\text { completion rate }\end{array}$} & PRIEDU & 85.818 & 185.296 & 14.093 & 21.837 & 2072 & WDI & $\%$ of relevant age group \\
\hline & $\mathrm{RD}$ & 6.335 & 475.667 & 0.00544 & 47.047 & 1466 & WDI & \\
\hline $\begin{array}{l}\text { Research and development } \\
\text { expenditure }\end{array}$ & $\ln (G D P)$ & 8.294 & 11.625 & 1.857 & 1.575 & 3168 & WDI & $\begin{array}{l}\% \text { of GDP } \\
\text { constant } 2010 \text { US\$ }\end{array}$ \\
\hline $\begin{array}{l}\text { GDP per capita } \\
\text { Gross fixed } \\
\text { capital formation }\end{array}$ & GFCF & 22.883 & 219.069 & -2.424 & 10.434 & 2942 & WDI & $\begin{array}{l}\% \text { of GDP } \\
\text { Index } \%\end{array}$ \\
\hline $\begin{array}{l}\text { Government } \\
\text { effectiveness }\end{array}$ & $\ln (G E)$ & 1.347 & 1.861 & 0.56 & 0.239 & 2690 & WDI & $\begin{array}{l}\text { of general } \\
\text { government health }\end{array}$ \\
\hline $\begin{array}{l}\text { Social security } \\
\text { funds }\end{array}$ & SS & 37.834 & 99.002 & 0.507 & 32.242 & 1915 & WHO & $\begin{array}{l}\text { expenditure } \\
\% \text { of private }\end{array}$ \\
\hline $\begin{array}{l}\text { Private insurance } \\
\text { payments }\end{array}$ & PRIVINS & 13.764 & 87.643 & 0.5 & 15.693 & 2205 & WHO & $\begin{array}{l}\text { health } \\
\text { expenditure }\end{array}$ \\
\hline
\end{tabular}

Time period: 1996-2014,

Number of cross

sections: 169

Table A2: Simple OLS Regression

Model: $H E P P P=\beta_{0}+\beta_{1} \ln (G D P)+\beta_{\mathbf{2}} \ln (G E)+\beta_{3} R D+\beta_{\mathbf{4}} P R I E D U+\beta_{5} S S+\beta_{6} P R I V I N S+\beta_{7} G F C F+\beta_{8} P G+$ $\beta, D U M M Y+s$

\begin{tabular}{|ll|}
\hline Variables & \multicolumn{1}{c|}{ OLS Regression } \\
\hline $\ln ($ GDP $)$ & $878.28 * * *(83.810)$ \\
$\ln (\mathrm{GE})$ & - \\
& $1347.88^{* * *}(386.626)$ \\
RD & $664.74^{* * *}(56.967)$ \\
PRIEDU & $-1.347(2.927)$ \\
SS & $-7.366^{* * *}(1.946)$ \\
PRIVINS & $1.883(2.777)$ \\
GFCF & $-11.773^{* * *(4.864)}$ \\
PG & $129.151^{* * *}(46.94)$ \\
DUMMY & $-513.46^{* * *}(194.881)$ \\
\hline
\end{tabular}

Number of Observations: 471

Number of Groups: 65

Standard errors in Parentheses 
International Journal of Humanities and Applied Social Science (IJHASS)

E-ISSN: 2471-7576

September 2020, Vol: 5, Issue: 9

E-mail: editor@ijhassnet.com

http://ijhassnet.com/_ DOI: 10.33642/ijhass.v5n9p3

CCenter for Promoting Education and Research (CPER) USA,www.cpernet.org

Table A3: Static and dynamic models.

\begin{tabular}{|c|c|c|c|c|}
\hline \multirow{2}{*}{$\begin{array}{c}\text { Variables } \\
\text { Dep. Var: } \ln (H E P P P)\end{array}$} & \multicolumn{2}{|c|}{ Static Model; Fixed Effect } & \multicolumn{2}{|c|}{ Dynamic Model } \\
\hline & Developed Countries & Developing Countries & Developed Countries & Developing Countries \\
\hline $\ln (G D P)$ & $1.826 * * *(0.813)$ & $1.895^{* * *}(0.085)$ & $0.383^{* *}(0.188)$ & $0.047(0.098)$ \\
\hline $\ln (G E)$ & $-0.635^{* *}(0.273)$ & $0.630^{* * *}(0.218)$ & $-0.431(0.441)$ & $0.819^{* *}(0.401)$ \\
\hline $\mathrm{RD}$ & $0.140^{* * *}(0.031)$ & $0.193^{* * *}(0.042)$ & $0.076 *(0.454)$ & $0.086(0.960)$ \\
\hline PRIEDU & $0.001(0.001)$ & $0.000(0.001)$ & $-0.008 *(0.004)$ & $0.003^{* *}(0.002)$ \\
\hline SS & $-0.005^{* * *}(0.001)$ & $-0.004^{* * *}(0.001)$ & $-0.009 * *(0.004)$ & $0.000(0.003)$ \\
\hline PRIVINS & $0.004^{* * *}(0.001)$ & $-0.003 *(0.001)$ & $-0.031^{* *}(0.015)$ & $-0.001(0.005)$ \\
\hline GFCF & $-0.023^{* * *}(0.002)$ & $-0.004(0.003)$ & $0.004(0.004)$ & $0.006(0.006)$ \\
\hline PG & $-0.128(0.195)$ & $-0.070 *(0.041)$ & $0.072(0.082)$ & $0.009(0.680)$ \\
\hline $\ln (H E P P P) . \mathrm{L} 1$. & & & $0.830^{* * *}(0.097)$ & $0.789^{* * *}(0.091)$ \\
\hline No of Observations & 167 & 304 & 164 & 295 \\
\hline No of Groups & 17 & 48 & 17 & 48 \\
\hline F-Statistics & 148.06 & 143.08 & & \\
\hline R-Square & 0.892 & 0.894 & & \\
\hline Prob $>$ F & 0.000 & 0.000 & & \\
\hline Wald Chi2 & & & 3242.77 & 1839.71 \\
\hline Prob $>$ Chi & & & 0.000 & 0.000 \\
\hline $\operatorname{AR}(1)$ & & & 0.005 & 0.041 \\
\hline $\mathrm{AR}(2)$ & & & 0.455 & 0.687 \\
\hline Hansen Test & & & 1 & 0.996 \\
\hline
\end{tabular}

